\title{
Is There a European Philosophy Science? \\ A WAKE-UP CALL ${ }^{1}$
}

\section{INTRODUCTION}

The short answer to this question is a firm and unambiguous "yes and no". The long answer will take the whole talk. Indeed, it could easily take an entire book. It is therefore unavoidable to take recourse here and there to simplifying shortcuts and polemical exaggerations, in order to get the message clear.

Let us go back to the short answer. Yes, there does exist a European philosophy of science. The Viennese meeting and generally our networking program (see fn 1), and all those participating European philosophers of science are ample proof of it. - No, there does not seem to be such a thing as European philosophy of science, because there are no genuinely European contributions to philosophy of science, or they are below the international perception threshold.

\section{II. “Globalization": its Impact on the History of Philosophy of}

SCIENCE

"Globalization" is a very complex phenomenon that relates to the global flow of goods, services, ideas and people. In almost all European countries we can observe how former economic strongholds have almost completely dissolved in the course of a few decades, following the capital maximizing logic of the markets. At the same time new forms of production or services develop. There are winners and losers of economic globalization. It seems almost certain that in the near future Europe will be among the losers.

What holds for goods and services holds also for ideas. The winners on the market of philosophical ideas receive global professional recognition and sometimes even fame, but also get more mundane goods as invitations to congresses, talks at foreign universities and good positioning on the job market. - I dare say that being a loser on the market of ideas for Europe is not any more the writing

1 The paper is based on a talk given in Vienna, in December 2011, at a joint conference of the "Vienna Circle Institute" and the "European Science Foundation Research Networking Programme The Philosophy of Science in a European Perspective (PSE)".

The topic of the conference was: Philosophy of Science in Europe - European Philosophy of Science and the Viennese Heritage. - The author would like to thank all people who have commented on the paper. 
on the wall that may become reality in some distant future; rather, we are losers already. In order to substantiate this thesis that to some might seem a bit exaggerated and even bold, we have above all to consider that ideas do not flow around the globe in a quasi Platonic, disembodied form. They come dressed up in languages. We all know that among the around 6500 languages of the world there is a chosen one. To have it, i.e. to have a lingua franca, is a good thing I hasten to add. English as the universal means of communication is of irreplaceable help and enormous importance in international exchange in all fields and on all levels. It can hardly be replaced by any other language or means of communication.

As everything, English as lingua franca comes at a price, which is, however, almost exclusively paid by non-native English speakers $\left(\right.$ NoNES $\left.^{2}\right){ }^{3}$ In the rest of my talk that deals only with European non-native English speakers of English the acronym NoNES is restricted to Europeans. "NES" is an acronym for native English speakers and all those, who work at universities in Anglophone countries, whereas "RoW" refers to the rest of the world outside Europe where English is not the first language.

The price that NoNES have to pay for the wrapping of their ideas in English is manifold: First of all they do not naturally have the wrapping paper, i.e. the English language at their disposal. This means that they have to spend time and money in order to learn English, and then spend more money, in order to have their work translated or corrected by a native speaker..$^{5}$ One of the many scarcities of nonAnglophone European Universities is that they do not offer linguistic services. A laudable exception is the Language Services of the University of Helsinki. There might be others, hopefully. I do not know, for example, of any German University that offers anything comparable with "Helsinki" to its faculty, although the average command of English among German academics seems to me clearly inferior to their Finnish colleagues. Second, even if NoNES are in a position to somehow wrap their ideas into English, such packing looks in most cases rather poor compared to the original. Third, this makes it almost certain that NoNES play a rather secondary role on the market of ideas. Fourth, as it sometimes also happens with material goods, the wrapping has an impact on the content. We know that some plastic containers are not suitable for food and drinks, because some containers

2 I take this abbreviation from Clavero 2010, 552. I like pronouncing it "nones"

3 On further reflection, also monolingual Anglophones pay an - intellectual - price (perhaps without realizing it), as long as one finds correct Wittgenstein's connection of understanding languages and understañding forms of life.

4 Note that for reasons of simplicity also native speakers of English working at European universities outside Britain and Ireland are counted as NoNES.

5 A NES reading this paper may have noticed well before that I have saved the money for having it edited by a native speaker. - I gratefully acknowledge, however, that a RoW with excellent knowledge of English has done very much to render an earlier version of the paper more readable. Since then it has been spoiled by many changes and additions. emit particles that affect the taste of the food and drink in question. Applied to ideas this means that English, or any other lingua franca, for that matter, might prevent some ideas from being optimally presented.

These four negative linguistic wrapping effects - I will later add three more and more important ones - are the smaller, the more formal, and the less culturally embedded a discipline is. It is certainly almost negligible in mathematics and formal logic. A bit less so it might be in physics and related "technical" disciplines. ${ }^{6}$

As we all know, modern philosophy of science has multiple origins. Its roots go as far back as into the $19^{\text {th }}$ and early $20^{\text {th }}$ centuries to people like Mach, Helmholtz, Poincaré, Duhem, Russell, Vailati, Twardowski ${ }^{7}$ and others. The most important sources seem to be, however, the Berlin and Vienna Circles in the 1920s and 30 s with a clear preponderance of the Viennese one. In Vienna Logical Empiricism originated, which has to be regarded as the nucleus of modern philosophy of science. In Vienna we find philosophical giants such as Rudolf Carnap, Carl Gustav Hempel (for a short time), Otto Neurath and Moritz Schlick. And in Vienna we are happy to celebrate these days the twentieth anniversary of the Institute $\mathrm{Vi}$ enna Circle (IVC), ingeniously founded and most successfully guided ever since by Friedrich Stadler. The IVC's work is dedicated to the preserving, propagating and advancing the precious intellectual heritage of Logical Empiricism.

What seems to us, or at least most of us, as a self-evident truth, namely that Logical Empiricism above all originated in Vienna, is completely ignored by others. Take e.g. the entry "Logical Positivism" in Robert Audi's much used Cambridge Dictionary of Philosophy of 1995, that entered unchanged into the second edition of 1999. The author is Richard A. Fumerton, F. Wendell Miller professor of philosophy at the University of Iowa. Here a quote from the first section (p. 514):

Logical positivism, also called positivism, a philosophical movement inspired by empiricism and verificationism; it began in the $1920 \mathrm{~s}$ and flourished for about twenty or thirty years. [...] In some ways logical positivism can be seen as a natural outgrowth of radical or British empiricism and logical atomism. The driving force of positivism may well have been adherence to the verifiability criterion for the meaningfulness of cognitive statements.

6 Mahoney. 2000. identifies respective problems in astronomy. - On the website of the British Parliament (www.parliament.uk) one finds a paper on peer review in form of "written evidence submitted by the Academy of Social Sciences (PR 26)". Among the "weaknesses of peer review" (p. 3) one looks in vain for the bias against nonAnglophone publications. It seems remarkable, nonetheless, that at least the non-Anglophone world is taken notice of: "Outside the Anglophone world, peer review is less dominant, although practices are tending to converge to this norm" (p. 4).

7 One should add that the whole Lvov-Warsaw School, which was founded by Twardowski, should be taken into account here. Cf. e.g. Woleński. 1989, Coniglione/Poli/Woleński eds. 1993, and the very useful edition of texts in German (Pearce/ Woleński eds.1988). 
What are we supposed to learn from this? ${ }^{8}$ Well, we learn that logical positivism, or, as I prefer to call it, logical empiricism, ${ }^{9}$ has completely British roots. It is characterized as "a natural outgrowth" of radical or British empiricism and logical atomism. As everybody will agree "radical or British empiricism" is somehow essentially British, and for "logical atomism" the Dictionary unsurprisingly refers to "Russell" who is described (p. 699) as "British philosopher, logician, social reformer, and man of letters, one of the founders of analytical philosophy". So I think it to be no exaggeration to conclude that logical empiricism is characterized in the Dictionary as a philosophical movement with exclusively British or AngloSaxon roots. I should add that the rest of the article does not use any proper names or indexicals that could give a hint to possible historical influences that are not of a British origin..$^{10}$ An innocent reader would conclude that "logical positivism" is part of the British, and of no other, philosophical tradition. Well, I think almost everybody outside the Anglophone world knows better, and knows better in the greatest detail. Nonetheless, I am afraid that Fumerton's article might be an indicator of what "globalization" has in store for philosophy in general and philosophy of science in particular. The wrapping of ideas has changed their content. In the case at hand it is, as Wesley Salmon once pointed out to me, probably the Anglophone wrapping of Logical Empiricism in Alfred Ayer's Language, Truth and Logic (1936). Ayer's book has been for some people in the Anglophone world the only source of information about logical empiricism."

\section{Globalized Parochialism}

There are, particularly in the U.S., many more examples that show a coarse grained perception and sometimes even a remarkable ignorance of rest of the world connected with a sort of almost natural disinterest. Here a recent exchange on the HOPOS mailing list: there was some guessing who taught "the first seminar" in the philosophy of science. On March 26, 2011 at 3:15 p.m. Sydney Axinn, professor emeritus of Temple University, now what is beautifully called "Courtesy Professor" at the University of South Florida, wrote the following: "What is reported as 'the first ... seminar in the philosophy of science ...' was given at the University of Pennsylvania by Edgar A. Singer, Jr. [...] Among Prof. Singer's students was C. West Churchman, who later became editor of the Philosophy of Science journal.

8 I more or less literally quote this passage from Wolters. 2003, $109 \mathrm{f}$.

9 For the history of labeling logical empiricism see Uebel (forthcoming).

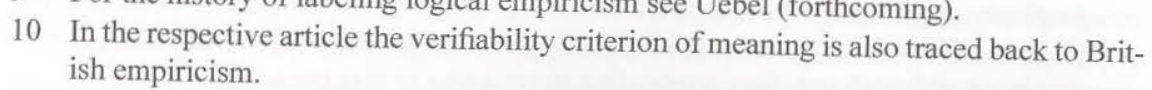

11 I should, however, add that a reader who follows the links given underneath the entry "logical positivism" is lead among other things to Thomas Uebel's splendid "Vienna Circle". - If one has a look at the "Board of Editorial Advisers" of the Dictionary one counts 26 NES and 2 NoNES ...
Less noteworthy students included the author of this note." - A quarter of an hour later that day Alan Richardson, an excellent scholar of $19^{\text {th }}$ and $20^{\text {th }}$ centuries philosophy, commented: "It should be noted that the issue that I [...] was attempting to sort through was philosophy of science in the USA [emphases are mine] - so even if we were to agree that Singer's course was the first US course with the title 'philosophy of science' this is not to say that there weren't courses given elsewhere with that name or a direct translation before then. After all, Mach was Professor of the Philosophy of the Inductive Sciences in Vienna from 1895." - This little exchange seems to be significant for a widespread attitude of self-satisfaction in the Anglophone world, particularly in the US. I mean a habit to spontaneously locate in their part of the world everything worth to be thought and spoken about. Only on further reflection may come to mind that this might not be the case. Such habitually narrow scope is usually called parochialism. In contrast to good old parochialism, which hardly ever crossed the borders of the respective parish, the new Anglophone variety can claim to be globalized parochialism.

To be sure, I do not see any malicious intent here in the sense that people consciously and explicitly might want to exclude the rest of the world. The rest of the world they simply take little notice of. ${ }^{12}$ I am sure that things were certainly not better if Finnish, French or German or any other language had become lingua franca. In my view globalized Anglophone parochialism has its roots in a general human habit to watch and judge things through the lens of one's own culture. ${ }^{13}$ This universal habit has been enforced in the case at hand by two more components. First, there is in my view no doubt that the Anglophone and in particular the US preponderance in the philosophy of science and in some other fields is well deserved. Second, and connected with the first, given the general economic and military and in their own view also cultural supremacy of the US, hardly any American thinks that there might be out there positive developments worth to take notice of. This seems the more natural approach to take since the knowledge of foreign languages is rather limited not only among NES in general but also in particular among NES philosophers of science. For presidential candidates of the Republican Party knowledge of foreign languages raises even the suspicion of lack of patriotism among many voters. ${ }^{14}$ And those who know foreign languages hardly ever read works written in those languages. A quick look in any bibliography of articles in Philosophy of Science or in books by NES authors gives statisti-

12 In Britain this attitude has been elevated to government policy: in 2004 pupils at age 14 were allowed to drop foreign languages. As was to be expected the youngsters drop them in fact on a huge scale, and replace e.g. French by "religious education". For more information see: http://www.independent.co.uk/news/education/educationnews/the-language-crisis-in-british-schools-2061211.html.

13 Note that also NoNES are often - and often rightly - accused of "eurocentrism" by the RoW.

14 Cf. McWorther (2012). - Suspects are the two former Mormon missionaries Huntsmen (Chinese) and Romney (French). 
cally very significant proof of this. Some NES, especially among our US friends, have even a sort of apriori knowledge that nothing worth to be taken notice of can come from outside the Anglophone world. It resembles very much the story told in the Gospel of St. John (I, 45f.), when Jesus collected his first disciples:

The day following Jesus would go forth into Galilee, and findeth Philip, and saith unto him: Follow me. Now Philip findeth Nathanael, and saith unto him: We have found him, of whom Moses in the law, and the prophets, did write, Jesus of Nazareth, the son of Joseph. And Nathanael said unto him: Can there any good thing come out of Nazareth? With this we have reached the present and turn to the question of how Anglophone
globalization affects theory.

\section{IV. “Globalization”: its Impact on Philosophical Theory}

As hinted to in the last section, the Anglophone preponderance in the philosophy of science is well deserved, notwithstanding the globalized parochialism that we find with some of its representatives. To their eternal praise I would even like to add that what is visible of European philosophy of science these days at least on a European level owes much to particularly one American institution: the Pittsburgh Center for Philosophy of Science that in the 52 years of its existence has probably done more for European philosophy of science than any European institution. Only the thus far two European networks in the philosophy of science designed and chaired by Maria Carla Galavotti are of similar importance. Many of us got to know each other via the Pittsburgh philosophical relay station. So, whatever critical things I have said about some Anglophone philosophers does not diminish the professional admiration and respect for many others, and particularly for the Center. ${ }^{15}$

When the Vienna and Berlin Circles fled Nazism in Austria and Germany there began what one might call the "professionalization" of philosophy of science, i.e. its exclusive concentration on more or less conceptual and technical problems. This meant considerably narrowing its focus. "Vienna", and to a lesser degree also "Berlin" had been different. Logical empiricism was embedded in both places in a major enlightenment movement that addressed society at large. The foundation of the Verein Ernst Mach (1928) and the so called Vienna Circle

15 The Center was founded in 1960 by Adolf Grünbaum. - One of its later directors, Gerald J. Massey, started in 1990 a special collaboration with the University of Konstanz, which included a still ongoing archival collaboration that brought to the Philosophisches Archiv at Konstanz a clone of the tro PhiScientific Philosophy. The holdings at Kor the Pittsburgh Archives for European scholars - Furthermore the collaboration included the "Pited for the use of Colloquia in the Philos of Colloquia in the Philosophy of Science", which thanks to Peter Machamer's untiring and generous efforts went to eight editions (the last in 2008).
Manifesto of 1929 are ample proof of the fact that the early logical empiricists saw their professional activity in a broader societal context, and tried to present their research in public lectures accessible to those interested in society at large. ${ }^{16}$ This approach got completely lost, when Carnap \& Co had reached the US. Until very recently it does not seem to have regained strength. It occurs to me that this also holds to a certain degree for other Anglophone countries. ${ }^{17}$

Here is what Michael Dummett, an excellent analytic philosopher from Oxford, and himself in his fight against racism a notable counterexample, testifies for the British case:

very few [in Britain] think that there's any call on them to be involved in any practica sense, and partly it's a tradition in this country, I must say, and not only amongst philosophers. Well, I was very impressed recently, a few years back. I and various other Italian philosophers, and other British ones as I recall it, we all published articles in an Italian daily newspaper on philosophy. Now, that's unthinkable in this country, absolutely unthinkable! [...] In France, and to a lesser extent in Italy, intellectuals generally and philosophers in particular are expected to make remarks on political and social questions.

Dummett points here to a remarkable difference in the role that philosophy or philosophy of science, for that matter, play in various non-Anglophone European countries, as e.g. in France, Italy, Finland or Germany. Let me say a word to the Finnish case. The eminent Finnish philosopher Georg Henrik von Wright (1916-2003) has not only written much admired books in English. Besides this as it were "professional" work he has published most interesting contributions to general philosophical and cultural questions addressed to the general public that in my view are inspired by his clear and rigorous philosophical thinking. As Ilkka Niiniluoto pointed out to me von Wright thus became "in the 1980s and 1990s [...] the leading intellectual in Finland and in Scandinavian countries". ${ }^{18}$ One example is his denouncing in 1967 of the Vietnam War. ${ }^{19}$ Only a part of this his work, collected in books in Swedish and Finnish, has been translated into English, or any other language a substantial number of people could read. Thus, in a sense, sadly, even von Wright himself seems to have internalized the more technical "professionalization" of philosophy of science and its separation from culture at large that happened to Logical Empiricism in the US.

Another example of embedding philosophy of science in general culture is the Constructivism of the so called Erlangen School in Germany, founded by the mathematician Paul Lorenzen (1915-1994) and the philosopher Wilhelm Kamlah

16 The papers of Thomas Mormann, Donata Romizzi and Günther Sandner (forthcoming in the Vienna Circle Yearbook, see reference to Uebel) dealt with this aspect of logical empiricism.

17 See Fara/Salles. 2006, 10

18 Personal communication February 11, 2012.

19 I take this from a moving memoir of von Wright's Finnish student, Lars Hertzberg. It can be found via a link in the Finnish Wikipedia entry "Georg Henrik von Wright". 
(1905-1976). Erlangen constructivism is a bold program, which attempts a sort of operational foundation of mathematics, physics, philosophy and also politics. Some texts were translated into English. ${ }^{20}$ To the best of my knowledge they were completely ignored. The same holds for the further development towards the so called "culturalistic" approach that has been put forward by Lorenzen's former student Peter Janich (2006). Here the focus is on the cultural implications and presuppositions that figure prominently in science and philosophy.

A third example is historical epistemology. Historical epistemology goes back to French thinkers like Gaston Bachelard (1884-1962) and George Canguilhem (1904-1995). Thanks to the efforts of Hans Jörg Rheinberger historical epistemology has gained some influence on a European scale. But it would be an exaggeration to say that it has entered the globalized scene of international, i.e. Anglophone philosophy of science. I cannot recall, for example, any article on this topic in recent editions of Philosophy of Science.

From these three examples - other people probably could easily add more we can take the following lesson: the price of globalization and so called professionalization, for that matter, would be for Europeans to give up the longstanding and in my view very important embedding of philosophy and philosophy of science in the cultural life of their countries. One may add this as the fifth negative linguistic wrapping effect to those four mentioned in section II. Renouncing the cultural embedding is both a disadvantage for the respective national cultures and for philosophy. With the financial crisis progressing tax-paying citizens and their politicians are tempted to ask themselves why they should pay for the ivory tower business of philosophers. It is perhaps no coincidence that philosophy seems most endangered in Britain these days, where at least one department of philosophy was shut down recently. ${ }^{21}$ Others might follow or have already followed in the meantime.

Besides this broad cultural approach to philosophy of science that fell victim to the Anglophone globalization, there are more professional European approaches in philosophy of science that were practically ignored by globalized parochialism. To name just three of certainly many more examples: first the work of the very interesting Italian philosopher of science Giulio Preti (1911-1972), to whom we owe among other things a fascinating pragmatist embedding of philosophy of science. Unfortunately, not a line seems to have been translated into English. ${ }^{22}$ Furthermore I would like to mention the Polish philosopher Leszek Nowak (1943-2009), who seems to have launched the contemporary debate on idealization and has greatly contributed to it. He is, nonetheless, rarely quoted, although a substantial part of his work is published in English: He just seems to have had the wrong address:

20 A fine overview in English of the various approaches one finds in Butts/Brown eds. 1989. It does not cover, however, the political dimension.

21 I mean philosophy at Keele.

22 Those, who read Italian may consult among other things the presentation of Preti's work given in Parrini/Scarantino eds. 2004.
University of Poznan ${ }^{23} \mathrm{~A}$ third example is the theory of truth approximation that has been developed by Theo Kuipers (2000), Ilkka Niiniluoto (1987) and others. Although there are publications in first rate Anglophone journals and although it is vividly discussed among European philosophers of science it has not been taken much notice of on the global level.

These and many possible other examples of genuinely European approaches that did not enter the globalized international scene show - as sixth negative wrapping effect - one very important thing: The agenda of what counts in philosophy of science is not set in Europe but rather in the Anglophone world, particularly in the US. Everything that does not fit to cultural habits and traditions in those parts of the world has little chance to surface. ${ }^{24} \mathrm{~A}$ rift even within Anglophone philosophy was pointed out to me by James R. Brown (Toronto):

Many [philosophical] topics are perfectly international, but many ethical/political issues are local. Canadian philosophers who work on Canadian issues (e.g. bioethics within a system of socialized medicine) cannot publish in the [American, G.W.] 'top' journals, so suffer for it.

This development is further intensified by the so called "Philosophical Gourmet Report", which claims to deliver a ranking that "primarily measures faculty quality and reputation". ${ }^{25}$ The top scorers in the "Gourmet Report" practically set the agenda for the rest of the world.

Top scorers of any sort not only set the agenda, they are also in a position to enforce it by their strong influence on grants and tenure. Here is what primatologist Carel van Schaik, who spent most of his career in the U.S., wrote me about this. Van Schaik certainly thinks of experiences in his own field, but things are probably not entirely different in philosophy: ${ }^{26}$

I think there is one important strategic factor why people behave in this parochial way: grants and tenure. I write for the people whom I know, and sometimes respect, but who will judge me for major decisions, be it acceptance of journal articles, awarding of grants or evaluations of tenure! This great guy in China that nobody has ever heard of will not affect my chances of getting tenure, etc. This problem can also be solved when the evaluation part (grants, articles, tenure) also becomes more fully international. And once everyone is fluent in the lingua franca, this is an achievable goal! And if Europeans (or Asians!) do excellent work, one day the self-appointed dominants and keepers of the flame will have to notice.

23 An excellent overview for the Italian reader both of Polish philosophy of science and of Nowak's work is given in Coniglione 2010. Francesco Coniglione also first pointed out to me Nowak's importance.

24 Jim Brown, personal communication. - I am also grateful to Jim for explaining to me the negative effects of the "Gourmet Report".

25 See: http://www.philosophicalgourmet.com/.

26 Personal communication February 3, 2012 . 
NES not only set the agenda but sometimes also determine the methods. Here is an example coming from the political scientist Andreas Bieler (Nottingham) ${ }^{27}$ Bieler in Bieler in much of his work follows a method that might be characterized as analytical narrative. This method, as distinguished from the nomological hypothesis confirmation method, seems to be very suited for large areas of history and the social sciences. When recently he submitted a paper to the journal International Organization with an almost exclusively American editorial board he received the following answer:

At IO board meetings in recent years, we have discussed this matter in some depth. We look for articles that state hypotheses drawn from theories of international relations, discuss the literature from which these theories and hypotheses are drawn, propose empirical tests of the hypotheses, and then present findings that advance the relevant theoretical debates. Your piece does not fit this model of an article.

This methodological inferiority complex has recently very fittingly been designated 'The Social Sciences Physics Envy'. ${ }^{28}$ I suppose that comparable tendencies of methodological imperialism hold true for philosophy of science, even if they are not pronounced as clearly as in the case at hand.

Unfortunately, the Anglophone perspective on philosophy has been more and more internalized even in non-Anglophone Europe: Invited speakers at European conferences include almost always NES, often the majority is NES, and sometimes one looks in vain for at least one speaker of the NoNES. ${ }^{29}$ In Anglophone countries, however, not having NoNES as invited speakers is rather the rule than the exception. Here is an example from the [Notizie Filosofiche] mailing list (March 26, 2012). For a conference at the "Institute of Philosophy" in London "in collaboration with the University of East Anglia and supported by the Mind Association" on the topic "Philosophical Insights" I count 5 invited speakers from Britain and 4 from North America. ${ }^{30}$ This selection indicates that the organizers do not expect any "philosophical insights" from NoNES.

It is interesting, not to say depressing, to see how Europeans deepen the fundamental asymmetry by almost slavishly following the newest fashions that are proclaimed in the "leading" journals in the field. - The key word "journal" brings me to the concluding section of my talk, which deals with journals, thus talking about the seventh negative linguistic wrapping effect.

27 Personal communication February 3, 2012.

28 New York Times April 1, 2012 (Kevin A. Clarke, David M. Primo). 29 A telling example of this conference policy is what is described in a circular in English ence $>$ Gesellschaft für Wissenschaftsphilosophie (GWP) e.V. $<$ " that is going to take place in March 2013. At this founding event of a German Society for Philosophy of Science that avoids the word "German" in its very name, one finds seven "keynote speakers": 4 NES, 1 Greek, and, after all, 2 Germans.

30 See: philosophy.sas.ac.uk/d/f/Philosophical Insights 21230612.pdf

\section{On the Perception Threshold in "Globalized" PhILOSOPHY OF SCIENCE}

Let me begin with a truism: In order to be perceived beyond the national scale one has to publish in English. I have got the impression that this in the meantime also holds for being taken notice of at home. The European Science Foundation has developed the so called European Reference Index for the Humanities (ERIH), which has appeared in two editions, the second in $2011 .{ }^{31}$ It contains sections for journals both in "philosophy" and in "philosophy of science", and groups the journals in three classes: (1) National; (2) International 1; (3) International 2.

"INT1" is defined as endowed "with high visibility and influence among researchers in the various research domains in different countries, regularly cited all over the world". - "INT2", in turn, has only "significant visibility and influence" and it lacks being "cited all over the world".

I am not going to criticize here the enterprise "Reference Index" as such. I would rather like to have a look at the criteria, which led the commission: "Any journal accepted in the ERIH list has to meet stringent benchmark standards: peer review of submissions, an active international editorial board [...], openness to new authors $[\ldots] . "$

I would like to concentrate on peer review and the "active international board" of the leading journals in our field. As far as peer review is concerned, there is a vivid international discussion also in other domains, not only in philosophy, that has led to the result that papers written by NoNES that come from institutions outside the NES world have a significantly lesser chance to be accepted. The reason for this is simple: the editors and peer reviewers are mostly NES, and mostly American.

I have done some empirical research with three journals in the course of 20 years and have checked editorial boards and reviewers for Philosophy of Science, The British Journal for Philosophy of Science, and Biology and Philosophy in the respective editions of 1990, 2000 and 2010. Although this does not warrant a quantitatively exact result, the figures I have found seem representative and are sobering. Although all three journals are ranked INT1 in the ERIH-Index, the editorial boards of Philosophy of Science and Biology and Philosophy show no great changes in their overwhelmingly NES composition during the last twenty years. The editorial board of Philosophy of Science consisted in 1990 of 40 peo-

31 Cf. http://www.esf.org/research-areas/humanities/erih-european-reference-index-forthe-humanities/erih-foreword.html. Here one finds links to the various lists - It is also explicitly stated (p. 2) that the "difference between the categories [...] is not of quality but of kind." - This is, of course, naïve nonsense because a publication in INT1 is judged better by everybody as one in INT2. And because publications in English count more, NAT papers can be simply forgotten. Several people from various countries told me that this has already become the procedure of hiring committees in their respective countries. 
ple, among them two NoNES; in 2000 we find 55 people, among them 4 NoNES and 1 RoW, while in 2010 of 44 members 2 are NoNES. The number of NoNES referees is also always well below ten percent. In 2010, for example we find 182 referees, among them 13 NoNES. Similar things as for Philosophy of Science hold for Biology and Philosophy, while at the British Journal for Philosophy of Science all members of the editorial board have been NES so far, while perhaps 17 of the 252 reviewers of the year 2010 have been NoNES. ${ }^{32}$

I think it justified to say that NoNES and even more RoW are marginalized in these three journals, ranked "INT1" in the ERIH-Index. I cannot detect much of "international editorial boards". Consequently there is a structural unfairness in these journals to aspiring non-Anglophone contributors, and certainly in other journals that I did not check as well. ${ }^{33}$ An exception is Erkenntnis, a journal that has had German editors so far. The board of Erkenntnis has consisted predominantly of NoNES but has always contained a fair number of NES. ${ }^{34}$ But, for what reason ever, Erkenntnis is ranked INT1 in the "Philosophy of Science"-section of the ERIH-Index, while it is only INT2 in "Philosophy".

If one now puts some hope on the new European Journal for Philosophy of Science, the journal of the newly founded European Philosophy of Science Association (EPSA), the disappointment gives way to embarrassment. For, here we find a clear case of self-discrimination: if I have counted correctly the editorial board consists of 31 people. A majority of 19 works at non-Anglophone European Universities. This does not sound bad, although the NoNES/Anglophone ratio $19 / 12$ seems somewhat out of balance, because NES are still represented at more than a third. ${ }^{35}$ However, of the 29 articles published in the first four issues of the

32 There is a certain uncertainty in these figures. Not all referees are known to me. I have then categorized those with a clearly English name as NES. The other names unknown to me I have checked on the internet. This little uncertainty does, however, not influence the general result.

33 Van Parijs 2002 and 2007 discusses the unfairness question. - I thank Werner Callebaut of the Konrad Lorenz Institute for Evolution and Cognition Research for directing my attention to the articles of van Parijs and Clavero.

34 In the last 20 years the percentage of NES on the editorial board of Erkenntnis oscillates between ca. 25 and 45 percent. One might speculate, whether the downgrading of Erkenntnis in "philosophy"-section of the ERIH-Index has possibly to do with the fact that there is no majority of NES on the board. So what the authors seem to interpret as "active international editorial board" might be missing in the case of Erkenntnis

35 The mostly Anglophone countries Britain and Ireland have a population of some 66,8 Million, while France has a populatiōn of about one million less, but together with the partly Francophone countries France, Belgium, Switzerland and Luxemburg it comes to clearly more French than English speakers in Europe. Germany with it comes tion of ca. 81,7 million together with Germ the Germanophone part of Switzerland (ca. 5 million) adds up to around 95 million Germanophones, which is the by far largest linguistic community in Europe. I have not mentioned yet other large linguistic communities like Italians (60,1 million), Spaniards (46 million), and many, many others, including such small ones like Estonians
European Journal for Philosophy of Science, all but 4 come from Anglophone countries. There is no time to discuss this remarkable result. ${ }^{36} \mathrm{I}$ would only like to say that, for whatever reason, the European Journal for Philosophy of Science has not yet made any tangible contribution to further the cause of non-Anglophone European philosophers of science.

In concluding I would like to state that there is not much of genuine non-Anglophone European philosophy of science that has crossed the perception threshold of "globalized" philosophy of science. I am confident that the PSE programs and other European projects, above all the newly founded European Philosophy of Science Association and hopefully also the European Journal for Philosophy of Science will contribute to improving this unsatisfactory situation.

\section{What Might Be Done?}

The admitted Anglophone superiority in the humanities does in my view not justify the degree of actual dominance, nor does it allow that the agenda id almost exclusively set by NES. How might the NoNES change this situation, which I regard as undeserved and unsatisfactory? ${ }^{37} \mathrm{My}$ own suggestions include the following:

(1) We ought to try to learn English as early and as well as possible. This is not only a question of personal will and determination but also of public structures, particularly schools. The most important example of a counterproductive public structure is dubbing. Although I know that people prefer dubbed movies and tv series to originals with subtitles I regard it as a great stupidity that in major European countries like France, Germany, Italy and Spain films are dubbed because the costs of dubbing are easily repaid. Whoever had the opportunity to live for a while in a non-dubbing country can testify what I experienced in recent years in Holland and Finland, namely that almost all younger people, from the supermarket cashier to the student of philosophy speak pretty good English. So my recommendation

(1,1 million speakers). - The European Union alone has a population of around 502,5 million people; the Anglophone part of it is slightly above $13 \%$. It goes further down, when we add those European countries that are not part of the EU (like Switzerland, Norway, Ukraine, Belarus, and others), while leaving out the controversial question, whether parts of Russia or Turkey are parts of Europe. Particularly Turkey with its lively scene in philosophy of science could be counted as "European" (cf. Irzik/Güzeldere eds., 2005, perhaps also Russia. - The result of our linguistic census is that Anglophones, while representing (depending on the meaning of "Europe") at most about 10 percent of the European population are more than three times as much represented on the editorial board of the European Journal for Philosophy of Science. (Figures from the English language Wikipedia). - On the ambiguities and difficulties of "Europe" the German reader may see the splendid book Osterhammel, 2009, 143ff.

36 I have been informally told that above all there is a severe lack of acceptable submissions of papers by NoNES. This might hopefully change in the future.

37 Some people, e.g. Van Parijs 2002, and Clavero 2010 speak even of "injustice" here. 
is: ban dubbing $!^{38}$ Nobody will doubt that only people with excellent command of English are in a position to submit articles to Anglophone journals. In addition, in discussions most of us give a rather clumsy impression compared to our NES friends. This is no wonder because we have to struggle not only with questions and problems but also with the language, in which they have to be answered.

(2) We should be aware that it is not sufficient to only produce thoughts; one also has to sell them. Apart from linguistic asymmetry NoNES are on the whole rather bad vendors. In other words, compared particularly to their American colleagues, Europeans are in a statistically very significant way just lousy in presenting their work. Primatologist Carel van Schaik observed the following:

I have recently visited some philosophical meetings in Europe, and I noted that many European philosophers present their work in a most unattractive way. If at a busy meeting with numerous presentations, one has to work very hard to figure out what the speaker is trying to say, one simply gives up and instead focuses on the talks that are easy to follow! So, another response [to my paper, G.W.] would be to make sure continentals produce better presentations, and so have more impact! ${ }^{30}$

(3) My third proposal regards the university system. Independent teaching and research starts in most European countries after many years, sometimes decades, of serving - in some cases even of slaving - as assistants or whatever. This is most unproductive because the best work is usually done by people under 50 . Professors should not aim at creating intellectual clones of themselves but rather independent, critical spirits, as is the rule in the Anglophone system, and a precondition for scientific creativity. The structural prerequisite for this is, however, the introduction of the tenure track system as it has been in use in the U.S. for a long time. Given the internal corruption, nepotism and clientelism in the universities of some European countries it should be excluded that somebody starts a tenure track carrier in the university, where he/she received his/her $\mathrm{PhD}$. There should be created an open job market as in the U.S.

(4) Compared to American top universities European universities are as a rule grossly underfinanced. Take Harvard, a university with 21.225 students. ${ }^{40}$ The "total operating expenses" as documented in the "Harvard University Financial Report Fiscal Year 2010" (p. 18) are $\$ 3,729,582,000 .{ }^{41}$ This equals as of today ( 31 March 2012) $€$ 2.794.583.251.The budget 2011 for the 9 universities $^{42}$ and sev-

38 Cf. Van Parijs 2007, 226ff.

39 Carel van Schaik (Zurich), personal communication (March 20, 2012).

40 Cf. the English Wikipedia entry "Harvard University".

41 Available at: http://www.google.de/url?sa=t\&rct=j\&q=operating\%20budget $\% 20$ harvard\%20universiy\&source $=$ web\&cd $=1 \&$ ved $=0$ CC4QFjAA\&url=http $\% 3 \mathrm{~A} \% 2 \mathrm{~F} \% 2 \mathrm{Fc}$ dn.wds.harvard.edu $\% 2 \mathrm{Ffad} \% 2 \mathrm{~F} 2010$ full_fin_report.pdf\&ei=cbp1T53hHdGOswbA 3ODDAw\&usg=AFQjCNFo3hpftBp2vesPqosigtR3-hPiYA\&cad=rja

42 Among them are large and old institutions with costly medical schools like Freiburg, Heidelberg and Tübingen. eral other academic institutions in the German Land Baden-Württemberg is about 150 million Euros smaller: $€$ 2.636.302.000. The number of students in BadenWürttemberg was, however, as of November 2010 at 294.362. This means that Baden-Württemberg spends less than 9.000 Euros/student compared to 131.664 at Harvard. This means that Harvard spends around 15 times as much per student than the comparatively well off Land of Baden-Württemberg does. I am afraid that the figures in other European countries ("Oxbridge" possibly excluded) are not much better. Certainly, not all American Universities are as rich as Harvard, but it seems clear that the operating expenses of the top institutions exceed by far everything what we might find in Europe. - Given this financial imbalance compared to U.S. top institutions it is astonishing what poor European universities, in fact, do still accomplish.

(5) Publishing in English is only a necessary condition for crossing the global perception threshold. Active networking has to be added. These two necessary conditions are, unfortunately, not jointly sufficient. Disappointments are unavoidable. For those feeling disappointed it might serve as a consolation that also in preglobalization times philosophical quality did not always suffice to be perceived and acknowledged. There have always been unrecognized geniuses ....

It seems to me that there is no separate path to avoid publishing in English. Ongoing resistance in major European countries like France and Germany is in my view counterproductive and doomed to fail. ${ }^{43}$

(6) NoNES should stay away as much as we can from seeing the philosophical world through the lenses of globalized parochialism. There are interesting and sometimes fascinating developments in our countries that do not surface globally. To notice them presupposes attentiveness to what is going on in other NoNES countries instead of staring like a rabbit caught in the headlights at the newest revelations arriving from the world of globalized parochialism. As remarked earlier, it is Maria Carla Galavotti's European "Networks" that have achieved more than any other European Institution to open our eyes for what our NoNES friends have achieved and are achieving. Therefore projects on a European level are very much desirable. If only the bureaucratic procedures with the European Science Foundation (here I have ample experience myself) and probably other European institutions were not as tiresome, unproductive and nerve-wracking as they are!

43 According to a letter in the HOPOS mailing list (January 13, 2012) there is being launched a new bilingual (articles in French and English) journal Lato Sensu - Revue de la Société de philosophie des sciences. I very much doubt that articles written in French in this journal will be read by NES. I just checked the first 2012 issue of Philosophy of Science. Of the many references in 9 articles not one relates to a publication in a language other than English. I think this finding is fairly representative, and I am afraid that it will hold lato sensu also for publications in Lato Sensu. - Apart from this it is interesting to note that in the name of the French society the word "French" is missing, as mutatis mutandis in their German counterpart, 
Butts, Robert E., James Robert Brown, eds. 1989. Constructivism and Science: Essays in Recent German Philosophy. Dordrecht: Kluwer

Clavero, Miguel. 2010. "Awkward wording. Rephrase": linguistic injustice in ecological journals. Trends in Ecology and Evolution 25: 552-553

Coniglione, Francesco, Roberto Poli, and Jan Woleński, eds. 1993. Polish Scientific Philosophy: the Lvov-Warsaw School, Amsterdam: Rodopoi

Coniglione, Francesco. 2010. Realtà e astrazione. Scuola Polacca ed epistemologia post-positivista. Rome: Bonanno

Fara, Rudolf, Maurice Salles. 2006. An interview with Michael Dummett: from analytical philosophy to voting analysis and beyond, London: LSE Research Online. Available at http://eprints.lse.ac.uk/archive/00000552

Fumerton, Richard A. 1999. Logical Positivism. In The Cambridge Dictionary of Philosophy, ed. Robert Audi, 514-516, $2^{\text {nd }}$ edition. Cambridge: Cambridge University Press

Irzik, Gürol, Güven Güzeldere, eds. 2005. Turkish Studies in the History and Philosophy of Science, Dordrecht: Springer

Janich, Peter. 2006. Kultur und Methode: Philosophie in einer wissenschaftlich geprägten Welt. Frankfurt: Suhrkamp

Kuipers, Theo. 2000. From Instrumentalism to Constructive Realism: on Some Relations between Confirmation, Empirical Progress, and Truth Approximation. Dordrecht: Kluwer

McWorther, J. 2012. When Does Speaking a Foreign Language Get a Candidate in Trouble? In The New Republic, January 23

Mahoney, T. J. 2001. The Problems of English as a Foreign Language in Professional Astronomy. In Organizations and Strategies in Astronomy, ed. A. Heck, 185-192. Dordrecht: Kluwer)

Niiniluoto, Ilkka. 1987. Truthlikeness. Dordrecht: Reidel

Osterhammel, Jürgen. 2009. Die Verwandlung der Welt. Eine Geschichte des 19. Jahrhunderts. München: C. H. Beck

Parrini, Paolo, Luca Maria Scarantino, eds. 2004. Il pensiero filosofico di Giulio Preti. Milano: Guerini

Pearce, David, Jan Woleński, eds. I988. Logischer Rationalismus: philosophische Schriften der Lemberg-Warschauer Schule. Frankfurt: Athenäum

Szaniawski, Klemens, ed. 1989. The Vienna Circle and the Lvov-Warsaw School. Dordrecht: Kluwer

Uebel, Thomas. 2011. Name ist Schall und Rauch? On Naming a Revolutionary Philosophy. In Philosophy of Science in Europe - European Phi- losophy of Science and the Viennese Heritage, eds. Maria Carla Galavotti, Elisabeth Nemeth, and Friedrich Stadler (in preparation). Dordrecht: Springer (Vienna Circle Institute Yearbook)

Van Parijs, Philippe. 2002. Linguistic Justice. Politics Philosophy Economics 1: $59-74$

Van Parijs, Philippe. 2007. Europe's Linguistic Challenge. In The Language Ouestion in Europe and Diverse Societies, eds. Dario Castiglione, Chris Longman, 215-251. Oxford: Hart

Longman, 215- Logic and philosophy in the Lvov-Warsaw school, Dordrecht: Kluwer

Wolters, Gereon. 2003. Carl Gustav Hempel - Pragmatic Empiricist. In Analytical and Continental Aspects of Logical Empiricism, eds. Paolo Parrini, Mesley C. Salmon, 109-122. Pittsburgh: University of Pittsburgh Press

Universität Konstanz

Fachbereich Philosophie

Universitätsstraße 10

78457 Konstanz

Gereon.Wolters@uni-konstanz.de 